\title{
(РЕ)СЕМАНТИЗАЦИЈА БОГОЈАВЉЕЊА НА НЕРИ У КОНТЕКСТУ ПЕРЦЕПЦИЈЕ ПОГРАНИЧЈА
}

У студији се на основу теренских истраживања Пољадије (Румунија, насеља Ланговет/Луговет (рум. Câmpia), Златица (рум. Zlatiţa) и Соколовац (рум. Socol)) разматра актуелна пракса обележавања Богојављења на реци Нери. Наиме, од 1990. године (ре)успостављен је обредни опход: након богослужења носи се литија до Нере, где се обавља освећење реке; део ритуалне праксе постаје и пливање за Часни крст; у обреду, осим становника из пограничних села - Соколовца (Румунија) и Врачевгаја (Србија), учествују и црквени великодостојници, а неретко и представници политичких институција. У првом делу прилога даје се преглед основних историјских података везаних за српску заједницу у Румунији у новијој историји као основа за разумевање историјских догађаја и реалија које су саговорници тематизовали кроз дискурс о Богојављењу. Други део разматрања доноси аналитички преглед (релативно малобројних) етнографских описа обележавања Богојављења на овом простору у периоду пре 1990, те коментарисане транскрипте разговора вођених на терену. У трећем сегменту сагледава се функционисање теме Богојављења на Нери у јавном дискурсу (локални медији и гласила српске мањине у Румунији, медији из Србије, укључујући и интернет портале усмерене на ширу публику, Фејсбук страну Богојављење на Нери, те садржаје са других друштвених мрежа). Коначно, у закључном поглављу актуелна пракса посматра се у идеолошко-историјском контексту (ретрадиционализација у постсоцијалистичким друштвима, хомогенизација националних идентитета и сл.), у контексту „спектаклизације“ ритуала, те и у контексту студија пограничја. Граница се отуда показује као стратификован, слојевит и процесуалан феномен у виђењу саговорника, а реална (преосмишљена) обредно-обичајна (сада и институционализована и „спектаклизована“) пракса обележавања Богојављења на Нери добија и нова значења: то више није само ритуал из домена традицијске културе, већ и начин јавног манифестовања заједничког (етничког и културног) идентитета заједница Срба са две стране границе, постајући не само културни, већ и вид потенцијално политичког симболичког капитала.

Кључне речи: Богојављење, Срби у Румунији, обред, институционализација, усмена историја, медијски дискурс, пограничје

\footnotetext{
${ }^{1}$ smiljana78@yahoo.com

${ }^{2}$ Прилог је настао као део рада на пројекту Истираживаюе истиорије и кулйуре Срба у Румунији Центра за истраживања и културу Срба у Румунији при Савезу Срба у Румунији.
} 


\section{1. Теренска истраживања Пољадије 2019. године}

Тим истраживача Балканолошког института САНУ и Института за књижевност и уметност у Београду у оквиру пројекта Истраживање историје и културе Срба у Румунији Центра за истраживања и културу Срба у Румунији при Савезу Срба у Румунији обавио је 2019. године истраживања Пољадије у насељима Ланговет/Луговет (рум. Сâmpia), Златица (рум. Zlatiţa) и Соколовац (рум. Socol). ${ }^{3}$ Теме предвиђене планом пројекта обухватиле су, осим традицијске културе, и усмену историју, а теренска методологија, базирана на разговорима отвореног типа, омогућила је и стицање увида у перцепцију свакодневице, која је на овом подручју битно обележена и искуством живота у пограничју.

Једна од тема коју су саговорници врло често спонтано уводили у разговор је обележавање Богојављења на Нери (у ком данас учествују становници из насеља са обе стране границе - Соколовца и Врачевгаја, а неретко и поједини из оближњих села), те је утисак истраживачког тима био да овај ритуал (данас и манифестација) за Србе у Пољадији има специфичан значај. Управо је то био подстицај да се ауторка овог прилога посвети ширем сагледавању семантике Богојављења на Нери у контексту перцепције пограничја. Отуда ће у првом делу прилога бити дат преглед основних историјских података везаних за српску заједницу у Румунији у новијој историји ${ }^{4}$, без претензије да се осветле сви сложени аспекти овог проблема (што би далеко надилазило домене филолошке компетенције ауторке). Намера је да се уводним историјским прегледом пружи основа за разумевање историјских догађаја и реалија које су саговорници тематизовали кроз дискурс о Богојављењу. Други део разматрања доноси аналитички преглед етнографских описа обележавања Богојављења на овом простору у периоду пре 1990, те коментарисане транскрипте разговора вођених на терену. У трећем сегменту сагледава се функционисање теме Богојављења на Нери у јавном дискурсу (локални медији и гласила српске мањине у Румунији, медији из Србије, укључујући и интернет портале усмерене на ширу публику, Фејсбук страну Богојављење на Нери, те садржаје са других друштвених мрежа). У закључном поглављу актуелна пракса посматра се у идеолошко-историјском контексту (ретрадиционализација у постсоцијалистичким друштвима, хомогенизација националних идентитета и сл.), у контексту „спектаклизације“ ритуала, те и у контексту студија пограничја.

\footnotetext{
${ }^{3}$ Према попису из 2011. године у Ланговету живи 286 Срба (54,6\%), у Златици 225 (34\%), а у Соколовцу 436 (63,6\%) (Степанов Љ., Степанов В., 2014).

${ }^{4}$ О Србима у Румунији у широкој историјској перспективи в. Церовић, 1997; о различитим теоријама о досељавању Срба у Банат в. преглед понуђен у Павловић 2012: 71-78 (ауторка даје шири списак релевантне историографске литературе); уп. и Филиповић, 1958б; за историју Срба у Пољадији в. и Лупуловић, Крстић, 1999: 12-29.
} 


\section{2. Пољадија као пограничје}

Област Пољадије у Румунији у геокултурном смислу чини континуум са подручјем јужног Баната у Србији. Реч је о области око доњег тока Нере, а српско становништво са овог подручја познато је и под називом Банатске Хере. До почетка 20. века јединствено, изразито мултиетничко и мултиконфесионално подручје Баната функционисало је као целина, али је овакво стање измењено након распада Аустроугарске, тј. поделом Баната након Првог светског рата ${ }^{5}$ између Краљевине Румуније, Краљевине СХC и Мађарске. Међутим, околности разграничења биле су, заправо, веома сложене и дуготрајне. Према Конвенцији о примирју од 13. новембра 1918. у састав новоформиране Краљевине СХС улазе Бачка, Барања и Темишварски Банат, али се демаркациона линија фебруара 1919. помера 10 километара источно од Темишвара. У то време је Темишварски Банат под влашћу Народне управе чије је компетенције признала српска влада (о организацији власти у овом периоду, коју је пратило и незадовољство и отпор несловенског становништва в. Церовић, 1997: 398-401). Версајским мировним уговором из 1919. утврђене су границе, при чему је као компромисно решење виђена подела Баната ${ }^{6}$, те 27. јула 1919. српска војска и администрација напуштају Темишварски Банат (исто: 410). Одлуке су потврђене Тријанонским споразумом из 1920.7 Ипак, питање коначног разграничења Краљевине СХС и Румуније било је спорно још неколико година, будући да је уговором у Севру остављена могућност размене појединих насеља уз саму границу, те је, практично, до коначног разграничења дошло тек 24. новембра 1923 (исто: 414).

\footnotetext{
${ }^{5}$ Ратна и поратна дешавања била су праћена сложеним социјалним и политичким околностима. Претензије Југословенског одбора на део Баната са Оршавом на Дунаву, Темишваром и територијом до ушћа Мориша у Тису изнесене су у Паризу већ 1915. године (Церовић, 1997: 380). Како се рат ближио крају, особито након пробоја Солунског фронта, на територији Војводине формирају се институције различитих народа, те Срби формирају Средишњи одбор за Бачку, Банат и Барању, чији је задатак био да покрене акцију за уједињење са матичном Србијом. Српски народни одбор у Банату, формиран је најпре као хуманитарна организација, али се крајем октобра претвара у политичку (исто: 382-386). Српско народно веће износи захтеве за присаједињење Србији и подржава Резолуцију независних Срба и Хрвата из Јужне Угарске од 24. и 25. октобра 1918 (исто: 391). Слућење распада Аустроугарске ситуацију у Темишварском Банату учинило је веома комплексном. Ово подручје постаје поприште социјалних и класних сукоба (отворено организовано деловање тзв. зеленог кадра, октобриста; нереди, пљачке, анархија - посебно у области Пољадије и Клисуре, исто: 348). Српска војска улази на територију Баната преко Дунава 6. новембра, креће се од Клисуре ка Пољадији и Темишвару (у који ступа 15. новембра), да би у Арад ушла 21. новембра 1918 (исто: 392-398).

${ }^{6} \mathrm{O}$ реакцијама Срба у румунском Банату на ток преговора, те о акцијама за присаједињење које су настављене и након мировне конференције в. Церовић, 1997: 404-406.

${ }^{7}$ О току мировне конференције в. детаљније у: Церовић, 1997: 410-414; о политичким околностима разграничења в. и Цветковић, 2011a: 25; Стојковић, 1990: 235-236.
} 
Административном поделом Срби постају мањински народ у Румунији (тада као део југословенске мањине), као и Румуни у Краљевини $\mathrm{CXC}^{8}$ (у Краљевину СХС досељава се у овом периоду из Румуније махом српско градско становништво (Павловић, 2012: 78), али и становници села из пограничја ${ }^{9}$ ). Мањинска права у области школства и црквеног живота (каква су функционисала и до почетка Првог светског рата у оквиру државног уређења у Аустроугарској) установљена су на Сабору у Сибиу 1919 (Церовић, 1997: 415). Даље уређење школства, културних установа и мањинских југословенских политичких институција регулисано је потписивањем Конвенције о културној и просветној сарадњи између Румуније и Југославије 1933 (Церовић, 1997: 418), којом је обезбеђено и ангажовање учитеља из Југославије (тзв. контрактуалних учитеља) у српским парохијским школама ${ }^{10}$, односно, реципрочно, учитеља из Румуније у румунским школама у Војводини (уп. Рорі, 1976). Овакав систем функционисао је од 1935. до 1948. У међуратном периоду делују српска културно-уметничка и певачка друштва, читаонице, библиотеке, спортска и друга удружења (Церовић, 1997: 418; Стојковић, 1990: 238; Павловић, 2012).

Последица разграничења, када је о области коју насељавају Банатске Хере реч, била је и остајање херских села са различитих страна границе ${ }^{11}$, што је утицало и на аспекте свакодневице ${ }^{12}$. Успостављањем границе подељени

\footnotetext{
${ }^{8}$ Разграничење је било засновано и на принципу етничког баланса, па је у Румунији остало приближно онолико Југословена (Срба, Хрвата, Карашеваца) колико и Румуна у Краљевини СХС (Стојковић, 1990: 235; Церовић, 1997: 413); о проблемима везаним за успостављање ове административне границе из угла балканолошких студија, уз упућивање на референтну литературу ослоњену на рецентна теренска истраживања в. Sikimić, 2014: 56-58; из перспективе румунске мањине у Југославији / Србији (од успостављања границе до актуелног тренутка), с посебним освртом на различите типове миграција (радне, политичке, мотивисане породичним разлозима), в. Sorescu-Marinkovic, 2016: 157-159.

9 Примера ради, из Соколовца се у периоду после Првог светског рата иселило 150 мештана (Лупуловић, Крстић, 1999: 21).

10 Српске парохијске (вероисповедне) школе успостављене су у доба владавине Марије Терезије (Стојковић, 1990: 237-238).

${ }^{11}$ Систематска теренска истраживања ове области у Југославији обављана су 1950. и 1953. Подаци о селима у Румунији реконструисани су на основу разговора са пресељеницима из Златице и Соколовца. Резултати истраживања објављени су у: Филиповић (ур.), 1958. Миленко Филиповић, на основу теренских налаза, констатује да су села чији становници себе сматрају Херама (а и околина их на исти начин перципира): „Лесковица, Луговет или Ланговет, Златица и Соколовац или Сакаловац на левој страни Нераља и сада у саставу Румуније, те Калуђерово, Кручица или Крушчица, Кусић, Црвена Црква, Врачев Гај и Паланка на десној страни Нераља“" (Филиповић, 1958а: 13).

${ }^{12}$ Реконструисање родбинских веза између фамилија у селима са различитих страна границе понуђено је у: Букуров и др., 1958; детаљни подаци о породичним везама, браковима, досељавањима и расељавањима становника села Соколовац у насеља Дубовац, Кусић, Паланка, Калуђерово, Врачевгај, Црвена Црква итд. у периоду од 1787. до 1950. дати су у:
} 
су и сеоски атари, при чему су имања коришћена као двовласничка све до 1948 (Букуров и др., 1958: 38). Истим механизмом прњавор манастира Кусић нашао се у оквирима Краљевине СХC, док је сам манастир припао Краљевини Румунији. ${ }^{13}$ Успостављање административне границе одразило се и на привреду, саобраћај, трговину (маргинализација до тада важних привредних и саобраћајних чворишта, нпр. Беле Цркве, в. Букуров, 1958; Николић, 1958).

Други светски рат у историји Срба у Румунији представља особито комплексан период. Сумарно речено, ово је раздобље обележено дезертерствима са Источног фронта, успостављањем (илегалних) антифашистичких организација, контактима са Народоноослободилачком војском са југословенске територије (посебно у пограничним областима). ${ }^{14}$ Преломни моменат представља капитулација Румуније 23. августа 1944, када на румунску територију улази Црвена Армија, те антифашистичке организације почињу да делују јавно и формира се Антифашистички словенски фронт (АСФ) (Церовић, 1997: 420; Цветковић, 2011а: 29). Почев од септембра 1944. део Срба прелази на југословенску територију и прикључује се Народноослободилачкој војсци Југославије. ${ }^{15}$ Крај рата обележен је и ширењем гласина о присаједињењу дела румунског Баната Југославији. ${ }^{16}$

Однос нових југословенских власти према овом питању мењао се током 1945, бивајући условљен осцилацијама на ширем политичком плану ${ }^{17}$, а

Лупуловић, Крстић, 1999: 47-101.

${ }^{13}$ Манастир Кусић из 17. века (према предању - задужбина српског деспота Јована (Бугарски, Степанов 2008: 160)) некада је био метох Студеничке лавре, а од 1772. године је припојен манастиру Златица (Костић, 1930: 13-14), који је, према предању, задужбина Светог Саве. Кусић је 1778. спаљен од стране Турака. При спровођењу аграрне реформе 1923. манастир остаје без икаквог иметка (исто: 16). Иако у рушевинама, наставио је да функционише као култно место: „У порушени манастир из далеких крајева Баната иако је манастир порушен и долазе и дан данас Срби и болни и здрави на молитву и утеху“ (исто: 19). Обновљен је 1930. године (исто: 19-20), али је због лоцираности у пограничју активност замрла (приступ манастиру био је практично онемогућен), и у другој деценији 20. века наново се нашао у рушевинама (Бугарски, 1994: 86; Бугарски, Степанов, 2008: 161). Манастир је 2002. обновљен личном иницијативом и прилогом жене пореклом из Ланговета (о чему су на терену добијене подробне информације; уп. Бугарски, Степанов, 2008: 161). У манастиру данас нема редовног богослужења, а у тренутку теренског истраживања био је закључан.

${ }^{14}$ Појава војних бегунаца региструје се већ од 1941. До првих контаката војних бегунаца са Титовим партизанима долази у Ченеју и Дињашу 1943, али се у области Клисуре антифашистичке активности (сарадња са партизанима, ширење пропагандног материјала и сл.) региструју још од 1941. Године 1943. основан је Антифашистички одбор Срба за Банат Румуније (Церовић, 1997: 421; Цветковић, 2011: 26-27).

15 Тај број се процењује на 2096 (према подацима из југословенских архивских извора (Цветковић, 2011a: 29)).

${ }^{16}$ Овакве идеје ширили су по српским селима и агитатори из Југославије, што је резултирало и репресивним контраакцијама румунских власти, посебно крајем 1944. и почетком 1945. године (Цветковић, 2011a: 31-39).

${ }^{17}$ Између осталог, новоформираној влади Петруа Грозе (Petru Groza) CCCP је гарантовао 
решавање територијалних питања било је посебно осетљиво када је о Пољадији и Клисури реч (Церовић, 1997: 423) ${ }^{18}$. Описана, сложена ситуација утицала је на потоње догађаје ${ }^{19}$, нарочито оне везане за кризу око Резолуције Информбироа. Није без значаја поменути да је око 100 српских породица (добровољаца у НОБ-у) из Ланговета, Златице и села у Дунавској клисури након завршетка Другог светског рата колонизовано у Белу Цркву (Филиповић, 1958б: 371), те да су се неке породице из Соколовца самоиницијативно иселиле у Југославију (Лупуловић, Крстић, 1999: 59).

У послератном периоду односи између Југославије и Румуније су релативно складни, а 1947. потписана је Конвенција о културној сарадњи (Церовић, 1997: 425; Стојковић, 1990: 239). ${ }^{20}$ Велики преокрет у међудржавним односима изазван је усвајањем Резолуције Информбироа јуна 1948, доводећи до потпуног прекида дипломатских, политичких, привредних и културних међудржавних веза Југославије и Румуније. У новонасталим околностима граница између Румуније и Југославије добила је и додатна значења: то више није била само линија разграничења државних територија, већ и граница два различита, супротстављена идеолошко-политичка система, важна у целовитом контексту геополитичког мапирања Европе (као и граница са Мађарском, Бугарском и Албанијом). Уз антијугословенску кампању, у овом периоду долази и до укидања српских вероисповедних школа, забране присуства југословенских контрактуалних наставника у школама, тј. и депортације оних који Резолуцију ИБ нису подржали (Церовић, 1997: 455; 428), уз остављање могућности школовања на матерњем језику у посебним одељењима државних румунских школа (Стојковић, 1990: 241; Павловић, 2012: 122). Такође, гаси се Савез словенских културно-демократских друштава (ССКДУР) (1952) (Стојковић, 1990: 241), са радом престају југословенска културна удружења, а штампа се укида (Церовић, 1997: 426-429). Раздобље је обележено и политичким поделама у самој српској

територијални интегритет (опширније о политичким околностима везаним за идеју присаједињења дела румунског Баната Југославији в. у: Цветковић, 2011a: 29-39; Шандру, 2011: 309-310).

${ }^{18}$ О активностима становништва Соколовца у партизанским акцијама 1943/44. в. Лупуловић, Крстић, 1999: 22; попис погинулих и преживелих у борбама на Источном фронту, као и попис страдалих у борби југословенских партизана и регуларне румунске војске у зиму 1943/44 код села Карбунари, те о добровољцима из Соколовца у Југословенској војсци у акцијама у Срему, Славонији и Барањи 1944/45. године в. исто: 22-23.

19 Већ 1945. године Словенски антифашистички фронт (САФ) је из политичких разлога трансформисан у Савез словенских културно-демократских друштава (ССКДУР); детаљније о околностима ове промене в. у Милин А. и Милин М., 2009: 11-13; уп. Церовић, 1997: 425; Стојковић, 1990: 240.

20 О интензивнијим прекограничним контактима (погранична трговина, одржавање породичних веза, похађање школе у Белој Цркви) у овом периоду сведоче и сећања старијих саговорника са којима је на терену разговарано. 
заједници (в. Милин А., Милин М., 2009: 13 -3521; Милин, 2011: 17-19; Церовић 1997: 427) (при чему сада из Југославије у Румунију емигрира и део стаљинистички оријентисаних Срба; Милин, 2011: 19), политичким прогонима ${ }^{22}$, уз паралелно позадинско деловање припадника југословенске Управе државне безбедности (УДБА) и румунског Министарства за државну безбедност (Departamentul Securităţii Statului - Securitatea). Период од 1951. до 1955. донео је и депортацију дела становништва из пограничних крајева (из насеља која су се налазила 20 до 25 километара у дубину румунске територије) у Бараган (детаљније в. у Стојковић, 1990: 241-242; Церовић, 1997 : 429-432; Милин и Степанов, 200223).

Када је о Пољадији реч, у овом периоду долази до покушаја илегалних прелазака границе, те је тако забележено да је група младића из Соколовца препливала Неру и настанила се у Белој Цркви (Лупуловић, Крстић, 1999: 59; аутори доносе и детаљан опис и попис становника Соколовца који су били политички гоњени, те оних који су депортовани у Бараган (18. јуна 1951, укупно 40 породица, исто: 25-27)). Затварање границе, резултирало је и прекидом функционисања једне од важних саобраћајница која је пролазила кроз пољадијско подручје, железничке пруге Оравица - Јасеново - Бела Црква - Базјаш (изграђене 1856) услед рушења моста на Нери код Соколовца $^{24}$, те, као и у другим пограничним областима, успостављањем строге граничне контроле.

${ }_{21}$ У овој монографији објављена је и документарна грађа у вези са поделама у оквиру ССКУДУР-а, агитационим и пропагандним антијугословенским деловањем неких од његових чланова у току 1948. године (Милин А. и Милин М., 2009: 38-298).

${ }^{22}$ Оптужбе су се односиле на ширење пројугословенских идеја, рад против државе, покушаје илегалних прелазака границе, а читава акција позната је као „Процес титоистичким, фашистичким, империјалистичким издајницима“ (Милин, 2011: 14). Документарна грађа везана за ово питање објављена је у: Milin M. i dr., 2011: 110-161; Милин, Мракић, 2011: 162-177; Милин А. и др. (ур.), 2011; Nistor, 2015 (нав. према Sorescu-Marinkovic, 2016: 158).

${ }^{23}$ У монографији је донесена и богата документарна грађа; у Бараган су депортовани и припадници других етничких група (укључујући и Румуне), сви они оцењени као „опасни елементи“ (Церовић, 1997: 429-432).

${ }^{24}$ Оба моста на Нери, железнички и дрвени, срушени су први пут од стране српске војске 1941, одмах након рата су обновљени, али су ван функције наново стављени у описаном политичком контексту (Лупуловић, Крстић, 1999: 25). Индикативан је начин на који истраживачи из Југославије о овој теми пишу 1958, будући да се рушење моста ни у једном од тада објављених текстова не помиње експлицитно, нпр.: „Врачев Гај је на железничкој прузи Бела Црква - Базјаш, некад најважнијој прузи бивше Аустро-Угарске монархије, која сада не ради“ (Букуров и др., 1958: 45); „Између Соколовца с леве стране и Врачев Гаја с десне стране одржавао се раније жив саобраћај преко Нерине долине. Некада најважнија пруга бивше Аустро-Угарске, Темишвар - Базјаш, и друм истог правца прелазе Неру и данас између Соколовца и Врачевгаја“ (Букуров, Филиповић, 1958: 53); „За данашњи саобраћај у овом крају од значаја су (...) железничка пруга Вршац - Бела Црква - Базјаш (део пруге од Беле Цркве до Базјаша није у саобраћају)“ (Николић, 1958: 67). 
Обнављање међудржавних контаката после 1955. доноси побољшање третмана југословенске мањине у Румунији: враћање могућности школовања на матерњем језику у државним основним школама, обнављање периодике, рад културно-уметничких друштава и фолклорних група (о културном животу у овом периоду в. детаљније у: Церовић, 1997: 433-434). Године 1965. у Румунију на власт долази Николаје Чаушеску (Nicolae Ceaușescu). У почетку води либералну политику, конституишући, међутим, од седамдесетих година режим заснован на култу личности, који ескалира од 1980, постајући изразито тоталитаран, диктаторски и репресиван. Услед овакве политике Румунија доживљава велику економску кризу и изолацију. ${ }^{25}$

Последњих година овог раздобља, у време изразито рестриктивне контроле становништва Румуније, која је посебно укључивала и контролисање излазака из земље (пасоши су држани у полицији, а за путовања су биле неопходне посебне дозволе чије је издавање укључивало сложен бирократски механизам), живот у пограничју специфичним је, у односу на друге области, чинило постојање институције тзв. малих пасоша (рум. legitimaţii de mic trafic), којима је становништву био омогућен контролисан, шестодневни боравак у суседној држави (Југославији), где се одлазило, између осталог, и у набавку намирница, беле технике и сл. (уп. и Sorescu-Marinkovic, 2016: 158). ${ }^{26}$

Након Револуције, тј. пада комунистичког режима у Румунији, уследио је транзициони период када румунско друштво постаје плуралистичко, отварајући се према европским интеграцијама (Румунија је чланица Европске уније постала 2007. године). Ове промене укључиле су и јачање институционалне подршке мањинским народима, те је, између осталог, 1990. формиран Демократски савез Срба у Румунији (данас - Савез Срба у Румунији) као кровна институција српске мањине. ${ }^{27}$

\footnotetext{
${ }^{25}$ О мањинској политици у Румунији од 1963 (када званични међудржавни односи Југославије и Румуније постају потпуно пријатељски) до 1989, уз анализу законске регулативе и начина њеног спровођења, али и односа југословенске дипломатије према овом питању (укључујући и однос југословенских власти према илегалним емигрантима - Србима из Румуније) в. Стојковић, 1990: 242-249.

${ }^{26}$ Сећања саговорника сведоче о одласцима у погранична места у Југославији о празницима, говоре о локалној трговини и сл., али и о бројним илегалним преласцима границе различито мотивисаним: од напред описаних активности до жеље за емигрирањем из политичких разлога. Попис становника Соколовца који се иселио у Југославију од 1950. до 1989. дат је у: Лупуловић, Крстић, 1999: 27.

До пада комунистичког режима у Румунији у пограничним пределима велику улогу имала је и телевизија, тј. информативни, образовни, културни, спортски и слични садржаји у ТВ програмима из тадашње СФРЈ. Српске ТВ канале становници Пољадије и данас прате, премда је улога српских медија донекле опала, будући да радио и телевизијски програми из Србије данас више нису једина могућност информисања и забаве (слична запажања у вези са актуелним стањем у Поморишју изнесена су у: Ћирковић, 2017: 532-533; о усвајању српског језика посредством телевизије и радија код Румуна в. Sorescu-Marinković, 2010; Сореску Маринковић, 2018).
}

${ }^{27}$ Теренски наративи везани за период после Револуције доминантно су обележени сећањима 


\section{3. Богојављење на Нери}

\section{1. Етнографски описи}

Деведесетих година 20. века (после пада комунистичког режима) дошло је до успостављања и делимичне институционализације обредне праксе везане за Богојављење на Нери у којој сада учествује становништво из насеља са обе стране границе - Соколовца и Врачевгаја (иначе удаљених око 3 километра). Централни елемент овог празника, освећење воде, одвијао се до тог тренутка у Соколовцу у цркви (за богојављенску воду везана су и на овом подручју веровања у магијску снагу и лустративно дејство ${ }^{28}$ ). Од 1990. (ре)успостављен је обредни опход: након богослужења носи се литија до Нере, где се обавља освећење реке; део ритуалне праксе постаје и пливање за Часни крст; у обреду, осим становника Соколовца и Врачевгаја, учествују и црквени великодостојници, а неретко и представници политичких институција (председници општина Бела Црква и Соколовац, посланик српске мањине у румунском парламенту, некада и представници Владе Војводине, Савеза Срба у Румунији).

(Релативно малобројни) етнографски описи из различитих периода не нуде сасвим јасне одговоре на питања о томе како је пре поменутог (ре)успостављања праксе овај обред изгледао. У студији заснованој на етнографским истраживањима са југословенске стране границе из педесетих година 20. века Софија Димитријевић Богојављење описује на следећи начин:

„Раније се светила вода на Јарузи. За време верског обреда свако би захватио стакленце или бокал воде из Јаруге и заједно са литијом вратио би се у цркву и воду ставио насред цркве. Увек је била велика гомила разних боца и бокала, те је свештеник ово поново осветио“ (Димитријевић, 1958: 301).

Пракса о којој је реч није прецизно локализована, али с обзиром на то да се говори о свећењу воде на Јарузи, нема сумње да се ради о подручју источно од Кусића до Врачевгаја (уп. Букуров, 1958: 24). У етнографској студији Народни живот и обичаји Клисураца и Пољадијаца Борислава Крстића (већ и у првом издању из 2002) дат је следећи опис:

„У селу Соколовцу вода се освећује на реци Нери. Тог дана после црквене службе верници са литијом и свештеником одлазе на реку Неру, где се обавља велико освећење воде. Често се догађа да су истог дана на Неру долазили и

на одласке у Југославију ради трговине (продаја робе на пијацама), сезонског рада, као и на цветање сиве економије (будући да су деведесете године донеле распад бивше СФРЈ, увођење економских санкција СРЈ и велику економску кризу). Данас Срби из Пољадије одржавају везе са сународницима из Србије на различите начине: кроз путовања везана за активности из домена културног аматеризма, стицањем образовања на факултетима у Србији, спорадичним одласцима у погранична насеља ради трговине, неговањем родбинских веза и сл.

${ }^{28}$ Уп. нпр.: И то су пре рекли стари људи, кад пођеш на пијаце, добро да полијеш ту робу, ту робу што носиш на пијаце да полијеш с том водом да би се сви грабили за ту робу што је носии... [2]. 
верници из Врачев Гаја (Србија), па су тада заједнички обављали овај црквени обред. Поред верског обреда сваки парохијан би захватио воде у стакленце или балон и заједно са литијом се поново вратио у цркву а судове с водом оставио у средишту цркве коју је свештеник поново осветио“ (Крстић, 2015: 152).

Сасвим минимално измењене реченице доноси и редукованији опис у монографији о Соколовцу коју, уз Крстића, потписује и Васа Лупуловић (,„ога дана после црквене службе верници са литијом и свештеником одлазе на реку Неру, где се обавља велико освећење воде. Често се догађа да су истог дана на Неру долазили и верници из Врачев Гаја па су тада заједнички обављали овај црквени обред“, Крстић, Лупуловић, 1999: 191), те је свакако реч о Крстићевом тексту. Упркос помињању ношења литије до Нере (чега у периоду пре Револуције тешко да је могло бити), нема помињања заједнички организоване и институционализоване праксе. ${ }^{29}$ Ипак, сва је прилика да је Крстићев текст припремљен знатно раније, те да за потребе поменутих књига није накнадно коригован, с обзиром да се у истој монографији о Соколовцу нуди и исцрпан опис првог заједничког обележавања Богојављења, и то из визуре Лупуловића, као иницијатора и учесника:

„На дан 18. јануара 1990. године организована је успешна свечаност на граници. Организатор ове манифестације био је месни свештеник Васа Лупуловић, а и тадашњи кнез соколовачки (...) Вадеан и Славољуб Новичић. На Богојављење организовано је велико освећење воде на реци Нери којом су приликом на румунској страни били окупљени Соколовчани, а на другој Врачевгајци (Југославија).

Истом приликом биле су присутне високе званице: сенатор за караш-северинску жупанију Антоније Јоргован, префект за Караш-северинску жупанију Ливију Спатару, заменик префекта Константин Стојаковић, југословенски генерални конзул у Темишвару, председник Демократског савеза Срба у Румунији, Миленко Лукић, професор Борислав Крстић, песник Славомир Гвозденовић, и још пуно других гостију.

О овом навелико су писала гласила Наша реч у Румунији и Вечерње новости (Југославија). Под насловом 'Сокол - Врачевгај, нови југословенско-румунски гранични прелаз' Вечерње новости бележе: 'Локалне власти и грађани румунског села Сокол и југословенског села Врачев Гај обележили су заједно хришћанску светковину Богојављење. Први пут од 1948. године мештани двају села насељених српским живљем које дели Дунав на улазу у Румунију могли су да се слободно друже и веселе. Божјој служби која је приређена поводом верског празника присуствовали су грађани оба села истовремено обележавајући и место за подизање моста ове године, где ће се на бази југословенско-румунског споразума налазити нови гранични прелаз““ (Лупуловић, Крстић, 1999: 28-29).

\footnotetext{
${ }^{29}$ У Крстићевој монографији Код Белог Брешка и око њега, објављеној 1987. године (Крстић, 1987), богојављенска обредност уопште се не помиње.
} 


\section{2. Саговорници на терену о Богојављењу на Нери}

У наставку су представљени на терену добијени наративи који тематизују новоуспостављену праксу обележавања Богојављења на Нери, са циљем да се утврди место и значај овог обредно-обичајног комплекса у контексту индивидуалних доживљаја искуства живота у пограничју.

У прва два случаја ([1], [2]) реч је о наративима у које се тема уводи спонтано, асоцијативним укључивањем у биографске и нарације из домена усмене историје, тј. у разговоре о свакодневици.

У примеру који следи саговорница (рођена 1934. у Соколовцу, удата у Белобрешку) говори о школовању у Белој Цркви које је прекинуто затварањем границе 1948. Овај догађај види се као нагли рез у простору који становништво у пограничју доводи у готово парадоксалну ситуацију (3aтворила се гранииа, ко је остао тамо, остао тамо, ко је овамо, овамо, и више нисмо могли да идемо ни тамо ни овамо), а одвојеност од породице у Соколовцу саговорница (тада дете) и њена сестра избегавају стицајем околности (будући да су се нешто пре тога разболеле, отац их је из Крушчице, где су боравиле код тетке, вратио кући на лечење). Представа затворене границе обликује се визуелно (Поред гранище, поред Нере биле оране фашије ('појас'), и жище бодљикаве, заграђене, ко плот), уз изражену афективну димензију (И онда то је било строго; Нисмо нико нигде, не, мрдли, нисмо смели ни да се приближимо поред Нераља). Саговорничино објашњење политичких околности рефлектује поимање сложених политичких процеса који се релативно поједностављују и перципирају као свађа двојице државника (Кад је било Борђу Деж и Тито су били покарани; И биле и жище те бодљикаве, докле год после ни се помирили...). Заоштравање међудржавних односа озбиљно се одразило и на аспекте свакодневног живота, те се кроз наратив развија широка епизода о позиву саговорничине сестре на саслушање због разговора са рођаком са друге стране границе док је чувала овце. Кроз тематизацију односа некад / сад, усмерену на перцепцију промене природе границе, уведена је тема Богојављења на Нери, сада заједничке праксе Врачевгајаца и Соколовчана, као опозит пређашњем доживљају реке Нере као непремостиве, па и опасне границе. ${ }^{30}$

30 Детаљи из сећање саговорнице врло су блиски опису који на темељу фактографских података нуди историчар Владмир Цветковић: „Граница између Југославије и Румуније, која је до 1948. године била отворена, постала је забрањена зона; саобраћајне везе су кидане немилосрдно (...) дуж границе су постављане ограде од бодљикаве жице, минска поља, бункери, ровови и слични објекти који су се могли наћи једино на фронту. (...) Доказ да се заправо и радило о фронту били су многобројни погранични инциденти у којима се готово свакодневно гинуло. (...) То ненормално стање на заједничкој југословенско-румунској граници највише проблема и невоља доносило је локалном становништву које је до тада одржавало интензивне везе са сународницима из другог дела Баната, без разлике да ли је реч била о Србима или Румунима. (...) уз саму граничну линију били су постављени веома снажни звучници који су ширили информације усменим путем, а који су се могли чути читав 
[1]

С: У школу кад сам пошла сам се разболела од богиња. Сам добила богиње. Деца, кад сам била у школу, сам добила богиње, и моја тетка дошла нас узела, и мене и моју сестру од стрица нас узела у Крушчицу код ње, пет километра. И онда кад се мајка разболела, ми смо седели мало код тетке, и јавила моја тетка мојем оцу, и он дође с колма до нас, и нас довезе кући у Соколовац. И ми док смо боловале да се излечимо, граница се тад затворила. Затворила се граница, ко је остао тамо, остао тамо, ко је овамо, овамо, и више нисмо могли да идемо ни тамо ни овамо. Граница се затворила. [...] Кад је било Ђорђу Деж и Тито су били покарани. И онда то је било строго. Поред границе, поред Нере биле оране фашије, и жице бодљикаве, заграђене, ко плот. И поред Дунава било, свуде. [...] су били правили фашије, тако се види орање, тако се звала, фашија, то орање. Ако се види да је неко прошо, се познаје де је прешо границу. И биле и жице те бодљикаве, докле год после ни се помирили. Нисмо нико нигде, не, мрдли, нисмо смели ни да се приближимо поред Нераља. Моја сестра, имали су овце, а она била удата, па ту у Пландиште поред Нераља она чувала овце. А један наш братић из Паланке, нашега деде, његове сестре унук, он пита: - Јел, како се ти зовеш? - одонуд, опет поред Нераља и чува ододнуд овце. А она каже: - Ја сам Љубица. - Па, како ти се зове фамилија? - Па, мој деда се зове, каже, Исидор, каже, Иванчетов. - Ееее, па каже, ми смо род, и моја је мајка, каже, из Сакаловца, то је, каже, твојега деде сестра, каже, баба Ина. - Ееее, па чула сам ја за њу! - каже, ова моа сестра. И она разговарала с братићом преко Нераља. И посе ишла на, војска је спазила, био опсерватор код гробље там, и онај је чуо да она разговара нешто сас овим из Србије, из Југославије. И је викали на одговорност код војске [cмех]. За шта је разговарала, зашто тај има. - Па, каже, то је мој род, мој братић, ја сам разговарала с њим, нисам разговарала ни за политику, ни за... Шта радимо, и ко смо, и шта смо, и тако, каже, а не, нисам му ја, млада, за политику, каже. Сам чувала моје овце, он чувао његове одонуд, каже, и, и ту смо се јавили један другем, каже, нисмо... - А била на одговорност. Била. Нити смео ко д-иде да се купа, нити да, а сад иду, сад Нера и одбила, узела једно два плаца овамо у Соколовац, према селу, одбила. Они сад прођу преко Нере, иду с оне стране не песак, преко Нере, то је наш, наша територија, Румуније, Нераљ се одбио на Румунију. Они иду тамо се сунчаду на тај песак преко Нере. На Богојављење Врачевгајци сваке године дођу сас, ово, летију, барјаци, и цео народ шта год је у цркву, дођу на Неру. И ови Соколовчани опет одовуд, сваке године на Богојављење, још иде свет, и од нас иде свет тамо да гледаду, и угазу за крс и они, угазу. Један из Беле Цркве опет угази. И пре му брат, каже, у-, увати крс. Богојављење зима, снег, и мразеви и то, лед, али увату. Иде свет. И они сваке године на Богојављење на Нераљ иду онде.

(БЕЛОБРЕШКА 1 СЂ) $)^{31}$

километар унутар југословенске територије. Овај начин пропаганде изузетно је иритирао југословенску Команду граничних јединица, свесну да то не може да спречи. Због тога, у зиму 1953. године, та команда је тражила да се са југословенске стране поставе велики панои са паролама или исто тако снажни звучници не би ли се на неки начин парирало румунској страни“ (Цветковић, 2011б: 87, 89).

${ }^{31}$ Ознаке снимака дају се према ознакама из Дигиталног архива Балканолошког института 
Тема Богојављења на Нери у следећи наратив (издвојен из разговора са саговорницом рођеном 1941. у Соколовцу, удатој у Ланговету где и данас живи) уведена је кроз причу о специфичном, пограничном положају Соколовца, илустрованим превазилажењем просторне баријере / границе аудитивном метафором са сакралним конотацијама (Кад лупа звоно у Врачевгај, y Сакаловаи се чује), уз указивање на постојање прекограничних родбинских веза (И, и тамо смо имали, моји су имали, та баба што је била удата код тога мојега, то дође парадеда, имао брата у Врачевгај). Специфичност положаја Соколовца и Врачевгаја води саговорницу реферирању на актуелну богојављенску обредност. Важност праксе за локално становништво показује се и кроз заинтересованост и учешће припадника различитих етничких група (Па, иду сви, и Цигани, и Румуни...), не само из Соколовца, већ и из других пољадијских и клисурских села. Дијахронијска димензија уведена је кроз питања истраживача, а у настојању да појасни аспекте контекста пограничја саговорница говори о некадашњој царини у Соколовцу и проблему моста на Нери (чија изградња, како ће бити у наставку показано, прераста и у топос политичког дискурса, те одјеке овог дискурса рефлектује и усмени наратив): И: Ту је била ћуприја, а сад нема? С: Па, сад је парамено ('напуштено') треба да се, пре викали да праву, да праву, да намешту ћуприју, ту де се пре прелазило, ту била пре царина, како да кажем.... Проблем границом подељених имања покреће проблем амбивалентности у поимању простора: породично имање је своје у туђем, те као такво постаје и вид симболичког капитала (И дошо неки да купи ту земльу и да, да потпишеду моји, да даду, и они нису тели. Каже: - Не дамо, нек остане да се зна да је то земьа наша, каже, временом, каже, куј зна како мож да биде, не...). Захтев истраживача за прецизнијим позиционирањем праксе у историјском контексту уводи и сећање на период репресије.

[2]

Па ми, како нам било, кад лупа звоно у Врачевгај, у Сакаловац се чује. Ми смо били одма ту поред границе знате. И смо били близо. Тунак. И, и тамо смо имали, моји су имали, та баба што је била удата код тога мојега, то дође парадеда, имао брата у Врачевгај. Она каже, кад се удала тамо: - Сина Живу сам оставила - каже, оставила га код стрица и код стрине кад ју умро човек, он био мали, она се удала у Врачевгај, и тамо роди другога сина, и они му опет бацили име Жива... [...] А ту је био Нераљ близо, ту се купали све, и богословење, и наши, нисте видли, ваљда има и код вас да, Сакаловац и Врачевга, увек на Богојављење водица кад се, дођеду тунака на ћуприју ту, се узима вода.

И: Е, то не знам како иде.

C: То се иде у цркву сас флашу за воде, знате, е ондак они иду сви на Нераљ, иде литија цела, свет, све тако флашама, а ови наши пређеду, како иде Не-

CAHY (DABI). 
раљ, тако, наши су одовуд и Врачевгајци одонуд. И ондак они фрљу крст, један крст фрљу у Нераљ. И ондак скочу и наши, и Румини и Срби, и ко увати крст код тога је крст, после опет догодине тај. А има неки из Белацркву већ неколико година све тај вато је.

И: Значи, како, одакле крене та литија?

С: Из цркве.

И: Од Врачевгај?

C: Од Врачевгај дође отуд, како је била граница, како је ћуприја тунак на Нераљ.

И: Ту је била ћуприја, а сад нема?

C: Па, сад је парашено ('напуштено'), треба да се, пре викали да праву, да праву, да намешту ћуприју, ту де се пре прелазило, ту била пре царина, како да кажем. Па имамо, ми имамо земљу тунака код Белацркве. И како ми био, још ми био човек жив [...] и дошо неки да купи ту земљу и да, да потпишеду моји, да даду, и они нису тели. Каже: - Не дамо, нек остане да се зна да је то земља наша, каже, временом, каже, куј зна како мож да биде, не.

И: Па имате и сад ту земљу?

С: Да, и сад имамо ту земљу тамо. Да.

И: И онда крене та литија и?

С: И онда дође литија тунак и тако како стоји Нераљ, они станеду одонуд, то и попа, све то и барјаци донеседу и све тако се то ради. Наши дођеду са Бело-, Соколовчани, идемо и ми одовуд да видимо.

И: Из Ланговет?

С: Да, из Ланговета, добро, ја сам тамо и рођена, има кој нису рођени па иду да виду. И ондак иду тако, и ондак [...]. И то све се завиће ту вода, то се, поји попа, долази неки пут и владика, и свакојако се скупу млоги попови. Јако је лепо то. Има у новине више пута, почедо да вам тражим новине, има туна.

И: Ал то иду само Срби или?

С: Па, иду сви, и Цигани, и Румуни...

$[\ldots]$

И: А кад је био комунизам, Чаушеску, ел тад, како било?

C: Па ондак није то било, знате, ондак се донесе вода у цркву, у канте, у ведpo, како да кажем, неке лонце велике се донесе у цркву, и тако и ми код нас. Ми не идемо нигде, ми идемо у цркву за воду ту. Донеседу тамо, и то попа свешта, и то држимо целу годину, то се, та се вода не поквари, да.

И: А сад, узме се вода на Нераљ?

C: Да, сад узмеду они, Сакаловчани, а ми наши узмемо у цркву. И то су пре рекли стари људи, кад пођеш на пијаце, добро да полијеш ту робу, ту робу што носиш на пијаце да полијеш с том водом да би се сви грабили за ту робу што је носиш [...].

И: А Врачевгајци у доба кад био Тито, рецимо, дал ишла литија тад? Кад био комунизам у Југославију?

C: Па, није се, нису ни они то, они су то после кад ово, кад се мало пуштило ондак се то, почело да се то долази. Нису ни они долазили, још, тако. А има доста године кад се, има доста године од кад се, што се каже, и иде. Пре 
нисмо смели ни да погледнемо тамо, да...

И: Нисте смели да погледнете?

С: Па није било, пре било страшно, да...

И: Како?

С: Па, одма си титоиста, титоиста ${ }^{32}$, да... Били ти опсерватори, имали на крај градина опсерватори велики били, војска су били, гледаду, свакојако било је. Ко је смео да иде тамо, да прође, да сече траву, да сече дрва, да... (ЛАНГОВЕТ 1 СЂ)

Примери који ће бити размотрени у наставку добијени су као одговор на директно питање истраживача о Богојављењу. Мотив Нере као реке која спаја и раздваја (у овом случају - две државе) јавља се у виђењу црквењака у Соколовцу (могуће као одјек званичног, јавног дискурса, будући да је саговорник и редован учесник у овој пракси):

\section{[3]}

То је једно, мислим за село, најлепше што може да буде, да. Јел да вам кажем нешто, може река да раздваја и да спаја два села, два села, ал ово је лепше што на Богојављење спаја две државе, значи два села која су јако близо, и Нера, само добро, то нема мост, јер после револуције, хиљаду деветсто осамдесет девете, и да има, све би било другачије и лепше, ал нешто је, нешто је, ко год дође и снима [...] Света пуно, нема ништа лепше. Можда је олуја, снег, киша, целу годину, нико не напушћа, сви чекају кад владике крсту крстом, прекрсту Неру, и да благосиљаду ту воду, и шта ја знам, и нешто, за мене је најлепше што може да буде. Богојављење и Ускрс.

(СОКОЛОВАЦ 1 СЪ)

Следећи транскрипт део је разговора са саговорником рођеним у Соколовцу 1945. године: први сегмент представља полилог истраживача, саговорника (C1) и његове супруге (C2) покренут истраживачевом жељом да јасније сагледа позицију често помињаних локација у Соколовцу (које имају и симболичку вредност) у реалном простору (царина, некадашњи мост и сл.); други сегмент иницира истраживачево настојање да добије што прецизнији опис Богојављења у актуелном тренутку, будући да је реч о саговорнику који је добро обавештен и о практичним аспектима организације (довођење електричне енергије; телефонски договори и сл.), те и редован учесник.

[4]

И: А де овде била царина?

C1: На лево, кад изађете из овога сокака, па право.

И: Па близу.

\footnotetext{
${ }^{32}$ Реч је о термину коришћеном у свим државама „народне демократије“ поводом Резолуције Информбироа (у конкретном случају - рум. titoişti), који је функционисао и у јавном дискурсу и званичној документацији.
} 
C1: Па близу, па до Врачевгаја [...] један километер, ај нека биде два, нема више од два километера. То се затворило четерес и седме године. То кад је био тај Тито, Стаљин, тај Информбиро, тај... Онда се то затворило, и до дана данашњег нема од тога ништа. А причало се да ће да бидне, шта ја знам, мост ће се гради, шта ја знам, нема од тога ништа, нема од тога ништа.

И: А биле ћуприје неке на Нераљ?

C: То је била ћуприја дрвена. А овамо испод мојега сокака куд је ишо воз, ту је била ћуприја гвојздена, гвојздена била. И пре неку годину ту је све Нераљ засуо, подигла се вода горе, ондак дошла велика вода, и ударило успон у ту ћуприју, и онако почела вода да плави... Ондак је покварили, овако, Румуни покварили, демонтирали.

С2: Коју ћуприју?

$\mathrm{C} 1$ : Ћуприју ову гвојзедну.

C2: Није то [...]. То су, по Други светски рат је бомбардовано.

$\mathrm{C} 1$ : Милице, то ми остало у сећању. Ја сам четерес пете рођен, као деца се играмо у сокак и тако сам био случајно....

$[\ldots]$

И: А кажите ми, овај, како буде овде за Богојављење?

C: Е, то је лепо. То је лепо. Ја не знам дал, има то забележено на те телефоне ко то зна да ради. Ја имам телефон и дете моје, не знам ја то да радим. Онда дође, дође наш владика, владика овденак, и то се они договориду телефоном, почим је разлика у тај сат између вас и нас. И ту на Нераљ, тунак се прави служба, све то по реду. И одонуд владика тај Ромунски из Вршца, и они то све фино. Струју узмеду одавде, те куће крај Нераља тунак, кућа последња, узмеду тамо преко Нераља да би имали они струје на [...] манифестације.

И: А ел се то иде прво у цркву?

С: Да, У цркву. И из цркве се крене тамо.

И: И шта се ради у цркву?

С: У цркву се служи служба. Да. И онда кад се враћа са Нераља, идемо опет у цркву и тамо дамо један леј да нам даду ту освећену воду, водицу, ел како да кажем, знате, то је...

И: А ел се носе барјаци?

С: Даааа, кад се иде. И барјаци и небо, не. И небо.

И: Шта је то небо?

C: Па то је као један кров, неки покривач се, то иде владика и ти попови.

И: Испод тога?

С: Испод тога. Ми кажемо овденака небо у Соколовац.

И: А ко носи барјаци?

С: Људи млади $[. .$.$] . Већ је то постало мало и проблематично... Као и свуд...$

И: А то небо ко носи?

С: Исто тако, како се они тамо међу њима договориду...

И: А кажите ми, од кад је то почело?

$\mathrm{C}$ : A, то је било још одавно, то је било, мисим још док није се граница затворила до четрдесет седме. Сад је почело после Револуције то је почело, после револуције.

И: Значи и пре четерес седме је било то да...? 
С: Да, да, да, да. То чујем ја, тако од света сам слушао. А ово сад, знамо сви ово.

(СОКОЛОВАЦ 2 СЂ)

У разговору са саговорницом из Соколовца (C1), рођеном 1940. и саговорником С2 истраживач најпре настоји да још једном осветли проблем моста на Нери, а потом и да се информише о евентуалној заједничкој пракси у доба пре Другог светског рата, при чему се у разговор спонтано уводи и виђење статуса традиционалних пракси Срба у Соколовцу и религиозности у доба социјализма, уз позитивну конотираност ${ }^{33}$.

[5]

C1 [саговорнику C2]: Дал памтиш кад су Илију покајита крстили? У Нераљ. Ћуприја дрвена, и ми деца, они га крстили покаити, га обукли у белу кошуљу, спуштили га у Нераљ, а ми деца, то не знам колико сам имала године, смо се пењали на ћуприју дрвену, и гледамо све тамо. Сад, кад је то било... [разговор о дечијим играма, Божићу, колиндање]

И: А кажите ми, јел тај обичај (колиндање) одржаван, рецимо, и у време социјализма? Јел се смело то?

С2: Још јаче него сад.

C1: Да, ондак је било, држало се како треба, а сад, после за време...

C2: Тако то било, онда су деца била кући, пуно кућа било света, моју кућу, у моју ди сам ја, деда Вита, мати, отац, ја и брат.

С1: Да, шес...

C2: Пет, пет,... [...] Нема, значи, нико ни те питао ништа.

$\mathrm{C} 1$ : Пуне куће било света.

C2: Није те нико питао ништа. Ја сам радио у задругу, сам био у цркву [...]

Значи, идем на службу ујутру, и неки пут, нисам био [...] ал сам ишо у цркву, сам био секретар партије, секретар омладине сам био, секретар партије. Нико није дошо да ме пита: - Шта тражиш ти у цркву?

$[\ldots]$

C1: Знаш кад је било строго, сад ја не знам...

C2: Кад је титовци, кад оно, да, сад ви знате боље да кажете.

$\mathrm{C} 1$ : Кад је мој син да иде у војску, онда, правили смо кући, ондак био онај полицајац Ште-, Штефан...

С2: Штафан.

$\mathrm{C} 1:$ Он нам дошо и каже да не правимо ларму, да, не, не смемо то да правимо, ондак и сачекао тамо на аутобус, и они певали још ту, ми смо и пратили, отишо у војску ондак, смо га пратили, и ондак он забранио, и тако смо дете испратили, и смо се растурили код...

$[\ldots]$

\footnotetext{
${ }^{33}$ Реч је, разуме се, о само једном од могућих вићења статуса традиције и религиозности уопште у доба комунизма; анализе индивидуалних сећања везаних за овај проблем показују, очекивано, широк спектар различитих ставова и наративних стратегија, те недоследност и флуидност (уп. Radulović, 2014: 40-46).
} 
И: И летије ишле, и...?

C2: Летије ишле, како да не. Литија ја ишла у суботу на Васкрсење, не?

С1: Да.

С2: Литија иде на Богојављење.

С1: Да.

С2: Литија иде на Ускрс...

С1: Да. На Дове...

$\mathrm{C} 2:[\ldots]$ Нико није дошо, пре тако време било, баш ондак било пуно село момака кад се носила летија...

$[\ldots]$

И: Али није се ишло на оно Богојављење на Нераљ?

С2: Се ишло.

C1: Пре. Пре.

С2: Пре није се ишло. Па није, није, нико то није.

$\mathrm{C} 1$ : После Револуције, од ондак је почело.

С2: Пре није се ишло.

И: Ал, значи, није се ишло, али пре, рецимо, пре четерес седме, то је било?

С2: Не знам.

И: Кад сте ви били дете?

C1: Нису ни стари, нису ни стари ишли. Ја не пантим то. Па била отворена граница, ондак није то био обичај. Сада од кад се затворила граница...

С2: Од деведесете, да, то је почело.

(СОКОЛОВАЦ 4 СЂ)

Из етнографских описа, наведених у претходном сегменту, те на основу сећања саговорника (и посредованих сећања која преносе, посебно у примеру [4], у којима је могуће рачунати и на механизме несвесне корекције), тешко је сасвим поуздано рећи да ли је било икакве заједничке праксе обележавања Богојављења у нпр. међуратном периоду, али чини се да, ако је и постојала, одвијала се спонтано, извесно није укључивала пливање за Часни крст и било који вид институционалне подршке.

\section{3. Богојављење на Нери у јавном дискурсу}

О Богојављењу на Нери редовно извештавају локални медији и гласила српске мањине у Румунији ${ }^{34}$, али и медији из Србије ${ }^{35}$, при чему се прилози појављују и у електронским медијима и на интернет порталима који су усмерени и на ширу публику ${ }^{36}$. Будући да је реч о једној од укупно

34 Емисије на српском Радио Темишвара, на пример (в. https://www.facebook.com/ bogojavljenjenaneri/videos/467677100582332/), приступљено 12. 2. 2020.

35 Нпр. http://radiobelacrkva.rs/bogojavljenje-na-reci-neri-video/; http://infobc.rs/tag/vracevgaj/; http://www.tvbanat.com/emisije/442/bogojavljenje-na-neri, http://www.belacrkvato.org/, приступљено 10. 2. 2020.

${ }^{36}$ Прилози, настали у продукцији Савеза Срба у Румунији, емитују се и на РТС-у, телевезији са 
40 акција које организује Савез Срба у Румунији (Степанов Љ., Степанов В., 2014: 76), репортаже о Богојављењу већ се традиционално сваке године појављују у гласилу ове организације, часопису Наша реч. О утицајности Hаше речи на српску заједницу у Пољадији (наравно, и у читавој Румунији, уп. Павловић, 2012: 193), речито сведочи чињеница да су саговорници истраживаче неретко упућивали управо на у том гласилу објављене прилоге као релевантни извор информација (нпр.: Има у новине више пута, почедо да вам тражим новине, има туна... [2]).

За анализу процеса семантизације Богојављења на Нери у овом контексту одабрана је репортажа објављена 2019. године (број 1509/1510), аутора Предрага Деспотовића. Посебан значај Богојављења на Нери истакнут је реферирањем на историјско-политички контекст, уз увођење библијског цитата:

„Још од прве половине деведесетих прошлог века, на обалама реке, која спаја две земље, окупљају се мештани Соколовца (Румунија) и Врачев Гаја (Србија) предвођени свештенством и, након освећења воде, заједнички пливају за Часни крст. Заједнички, једног јединог дана у години, одламају, и не само симболично, (не)видљиви терет стогодишњег разграничења, преносећи вољом Тројединога јединствену поруку: А ко има уши да чује, нека чује“.

У представљању сусрета границом подељеног народа инсистира се на ритуално-симболичком плану (,Часни крст носиле су на белом платну две девојчице, Ивана из Соколовца и Наталија из Бијељине (...) а на челу колоне вијорио се српски барјак"), али се у текст уводи и слика емоционалних реакција учесника („Познаници и пријатељи са обе стране реке, па и родбина, махали су и довикивали једни другима радујући се још једном сусрету“). У закључном делу репортаже аутор се донекле поиграва појмом границе као метафоре:

„Ңување обичаја, поготово оваквих, који изискују и посебну физичку издржљивост, није ни мало лако, баш као ни вишевековно очување свести у, понекад, најтежим условима изолације и прогона. Оно што одржава и јача осећај припадности једном и недељивости завређује свако (само)одрицање. А поме-

националном фреквенцијом у Србији, као и на новосадској ТВ Панонији, телевизији Б92 итд. Занимљиво је, међутим, осмотрити неке од пратећих текстова. Тако је у тексту Duhovni most preko Nere (са интернет портала vesti-online) индикативан део антрефилеа, у ком се читаоцима из Србије Соколовац у Румунији приближава реферирањем на једног од најпознатијих фудбалера Црвене Звезде из деведесетих година: „Bogojavljenje na Neri, jedinstven događaj u celokupnom srpskom rasejanju koji s velikim interesovanjem svake zime očekuju vernici sa leve i desne obale ove reke, pogotovo oni iz Vračevog Gaja u Srbiji i Sokolovca u Rumuniji, rodnom mestu čuvenog fudbalera bukureštanske Steaue i beogradske Crvene zvezde Miodraga Belodedića, održan je u nedelju 19. januara“, https://www.vesti-online.com/duhovni-most-preko-nere /?fbclid=IwAR1TGw9OZVIWWetxWih8xKSKQLifNJGUkT0fFGA5GqeIEqZrPiSJQx QqkPk, приступљено 1. 3. 2020. 
рање граница, па и граница физичке издржљивости може се постићи једино непоколебљивом вољом. И вером.“

Семантика Богојављења на Нери примарно се види као модус манифестовања заједничког етничког идентитета становника са две стране границе и у садржајима које објављује истоимена Фејсбук страна (преко које, између осталог, заинтересовани могу слати пријаве за учешће у пливању за Часни крст, а окренута је и праћењу активности Савеза Срба у Румунији, као и обавештавању о значајним догађајима везаним за Српску православну цркву).

„На реци Нери, граници између Србије и Румуније, традиционално се одржава пливање за часни крст, на празник Богојављење. Литије крећу из насеља Врачев Гај, у Србији, и места Соколовац (насељен претежно Србима) у Румунији. Литије предводе владике банатски и темишварски Српске православне цркве уз учешће свештенства из Србије и Румуније као и верног народа. После службе и освећења реке Нере, која и том тренутку постаје „банатски Јордан“, Часни крст се пушта у воду и то наизменично једне године са српске, а друге са румунске стране. Пливачи за крст су углавном белоцрквански спортисти и рекреативци. Програм прати и озвучење са обе стране реке, што многобројним посетиоцима употпуњује доживљај.“

Слични се мотиви могу наћи и уз коментаре снимака на поменутом ФБ профилу, али из уз оне које учесници постављају у друге сегменте виртуелног простора (посебно You Tube).

„Бог се јави! ‡

Традиционално, од 1991. године на Богојављење сабире се српски народ са обе стране реке Нере, раздвојен 1919. године повлачењем границе између Србије и Румуније. На обалама реке у близини места Врачев Гај у Србији и Соколовац у Румунији, уз присуство и чинодејствовање епископа и свештенства банатске и темишварске епархије Српске Православне Цркве, обављен је чин освећења реке Нере, која у том тренутку представља банатски Јордан у коме је крштен господ и спаситељ Исус Христос. Као и сваке године до сада, након чина освећења, уприличено је плавање за богојављенски Часни крст.

Да река Нера и даље спаја један народ са две обале реке и нека би дао господ да се ово место уреди и овај догађај омасови и подигне на један виши ниво. Поред моста који је деценијска жеља народа, епископ банатски је пожелео да неке наредне године овом догађају присуствује и Патријарх.

Нек' је на здравље и спасење свима присутнима данас као и онима који су далеко, а мислима су у своме завичају, јужном Банату, Пољадији, Србији и Румунији. Амин Боже дај.“

Као један од стабилних мотива у обраћањима представника цркве и политичких институција (која неретко преносе штампани и електронски медији) јавља се и проблем моста на Нери, који, у овом контексту, поприма битна симболичка значења, евоцирајући, између осталог, и историјску 
димензију (рушење моста као симбол раздвајања заједница). У обраћању Славомира Гвозденовића, проблем моста на Нери актуализује се и као политички (за отварање граничног прелаза Соколовац - Врачев Гај добијена је иначе сагласност централних и жупанијских власти (Лупуловић, Крстић 1999: 28), али овај проблем још увек није решен), а идентитетски дискурс надограђује се увођењем језика и вере као симбола идентитета.

„Ваша преосвештенства, високопреподобна Мати Теофанија, пречасни и час-
ни оци, драги наши са обе стране обале, данас смо срећни као и сваке године
што имамо прилику да се на овај свети дан видимо, да се подсетимо да смо
један род, да се подсетимо да смо своји на своме, и да се, ево данас, понада-
мо да ћемо закорачити тим мостом једни према другима. Свих ових година
и општинске власти из две општине, а и наше маленкости у Букурешту и
Београду, трудили смо се, сваки на свој начин да овај мост заживи. Дај Боже
да тако буде. Али и пре и после моста ми остајемо родови, остајемо оно што
су нам били дедови и очеви, и што ће сигурно, с божјом помоћи и благосло-
вом, бити и наша деца, чувајући свој језик, веру, име и културу. Животом смо
заинтересовани, сигуран сам, обе националне мањине, и српска у Румунији
и румунска у Србији, да добросуседски и пријатељски односи између две
земље буду још бољи, а на тај ћемо начин једни бити ближи другима, а ја у то
име поздрављам све, сав овај наш народ окупљен на једној и на другој обали,
поздрављам све пријатеље, све које сарађујемо свих ових година, са којима
смо, практично, заједно. Нека на Бог помогне, нека Бог помогне Србији и
Румунији и Бог се јави!“ (из обраћања Славомира Гвозденовића, посланика
српске мањине у румунском парламенту, 2015). ${ }^{37}$

Занимљиво је да се поменути мотиви инкорпорирају и у домен тзв. „наивног стваралаштва“. Конкретно, уведени су у једну ауторску здравицу коју је 2019. као део програма извео представник Удружења Мојковчана. Сличне здравице су, иначе, последњих година често саставни део програма различитих манифестација (в. детаљније у: Ђорђевић Белић, 2018), а промена контекста извођења (традицијски / сценски / контекст манифестације) у већој или мањој мери рефлектује се и на текст. У здравици о којој је реч изразита је редукција традиционалних елемената вербалног израза (изостанак импровизације, редукција и трансформација карактеристичних традиционалних формула наздрављања и њихова трансформација: Нек се овај дан вечно слави / Нек радост и љубав одзвана, / На радост свакој српској глави, / Поздравља вас удружење Мојковчана), уз наглашенију аутореференцијалност (колективно ми, уз увођење историјских, конфесионалних и традиционалних симбола у одређење идентитета - Поздрављају вас потомии мојковачких јунака, / Где се Божић посебно слави...). Палета добрих жеља (које се упућују колективном адресату - присутнима (који се одређују као браћа)

\footnotetext{
${ }^{37}$ Извор:https://www.facebook.com/comuna.socol/videos/854906441221879/UzpfSTIwOTEzNzQwNT gxNzIxMTo4NDc3NjY1Mzg2MjA5NTg/, приступљено 15. 8. 2019, текст са снимка транскрибовала ауторка прилога.
} 
али и свакој српској глави) допуњена је и жељама за бољитком који се дефинише и укључивањем мотива везаних за изградњу моста на Нери.

Бог се јави! Бог нас је спојио и река Нера.

Једна река исти народ спаја,

На две обале молитва је иста,

Божанска је љубав Врачевгаја

Са браћом из Соколовца за вађење крста.

Овде је јутрос посебна зора,

Нера протиче освештана,

Уз благослов владике Никанора

И владике Лукијана.

Нек се овај дан вечно слави,

Нек радост и љубав одзвања,

На радост свакој српској глави,

Поздравља вас Удружење Мојковчана.

Поздрављају вас потомци мојковачких јунака,

Где се Божић посебно слави,

Истину зна свака $[\ldots]$ травка,

Помаже Бог, браћо Срби, и Бог се јави!

Највећа истина је љубав и у Бога вера,

Та је вера једна захтевност,

Бог се јави, а очекује Нера

Да се следеће године освешта мост.

Поносно, браћо, с љубављу да се слави,

Поносно кличем: - Бог се јави! ${ }^{38}$

\section{4. Ка спектаклизацији Богојављење на Нери: граница од административне линије до симбола са много лица}

Описана ресемантизација ритуалне праксе везане за Богојављење била је омогућена новим политичко-идеолошким контекстима формираним у обе државе крајем осамдесетих и почетком деведесетих година 20. века (падом комунистичког режима и трендом либерализације у Румунији, укључујући и формирање институционалне подршке мањинским народима, тј. трендом ретрадиционализације и хомогенизације националних идентитета, израженим у Југославији од друге половине осамдесетих година 20. века, а посебно деведесетих, које су обележили и грађански ратови на територији бивше СФРЈ). Тако у вези са проблемом религиозног живота у постсоцијалистичкој Србији Лидија Радуловић сумарно истиче:

\footnotetext{
${ }^{38}$ Извор: https://www.facebook.com/bogojavljenjenaneri/videos/232737430937949/, приступљено 15. 8. 2019, текст са снимка транскрибовала ауторка прилога.
} 
„Retradicionalizacija započeta u drugoj polovini osamdesetih, u svim sferama društvenog, političkog, privatnog i svakodnevnog života, različitim tempom, društvenim i političkim strategijama i posledicama koje izaziva, podrazumevala je i povratak religijskoj tradiciji. U javnom životu, retradicionalizacija pod uticajem crkve i politike značila je povratak pravoslavnoj tradiciji, dok je u privatnim životima građana Srbije podrazumevala i povratak takozvanoj tradicijskoj kulturi i formama narodne pobožnosti““ (Radulović 2014: 36) (о овом феномену на постјугословенским просторима в. и Naumović 1996; 2009; Perica, 2006; Radulović, 2012; 2014).

Сличне су тенденције опажене и у постсоцијалистичкој Румунији, те тако Сорин Гог, широко контекстуализујући проблем, истиче и методолошке проблеме проучавања поменутог феномена: „,The analysis of the realm of religious ideas and beliefs has to take into consideration at least two sub-dimensions: general religious ideas (that do not always represent a genuine indicator of religiosity, they can mean as well only the presence of a diffuse residue of religious representations) and specific and historical institutionalized religious ideas (in the case of Romania, the Christian religious ideas) " (Gog, 2006: 40). Аутор, коначно, закључује:

„On a general level Romania is one of the most religious countries of both Eastern and Western Europe, in spite of more than half of a century of forced atheization and ideologization of the public sphere. But (...) the religious mentalities are strongly dependent of a specific socio-anthropological background: one that has a strong lack of modernization, i.e. a high rural sector, low educational capital, weak industrialization. Romania is one of the most religious countries in Europe precisely because it has one of the least modernized social systems on the old continent" (исто: 52).

Када је реч о традиционалним праксама Срба у Румунији у актуелном тренутку, на основу теренских истраживања традиције Срба у Темишвару, Мирјана Павловић указала је на улогу ритуала као вида потврде етничког идентитета, примећујући да се обнављање традиционалних празника у организационом смислу све више преноси у оквире цркве и мањинских организација, истичући и улогу ових институција у њиховом пропагирању, осмишљавању значења, уз регистровање улоге медија у поменутим процесима (Павловић, 2012: 206-207). Проучавајући трансформације обичаја кумачење код Срба у Дунавској Клисури, Биљана Сикимић указује на чињеницу да се ови процеси крећу и у правцу ,'Употребе' традицијске културе, од конзумеристичке комодификације до националистичке инструментализације“" (Сикимић, 2018: 320). ${ }^{39}$

\footnotetext{
${ }^{39} \mathrm{O}$ обнови религиозности у различитим постсоцијалистичким друштвима в. и Borowik i dr, 2004; Baeva and Valtchinova, 2009: 317-318; Беновска-Събкова, 1999; 2013; неки истраживачи говоре и о глобалном тренду повратка религиозности од осамдесетих година 20. века (о чему детаљније у Беновска-Събкова, 2013: 249; Gog, 2006, уз упућивање на релевантну литературу).
} 
Додатно, увођење нових елемената (укључивање државних симбола, парола и сл. у иконографију, обраћање црквених великодостојника и представника политичких институција са неке врсте сасвим импровизоване сцене, те медијска подршка) дозвољавају да се о Богојављењу на Нери говори и као о виду „спектаклизације ритуала“ (Лукић Крстановић, 2010: $50^{40}$ ).

Суочавање са искуствима (ре)успостављања и (ре)дефинисања политичких граница, миграција, живота у дијаспори, опозитним тенденцијама мултикултурализма и национализама, глобализације и сепаратистичких тенденција, као европским, али и глобалним феноменима, одвело је антрополошка проучавања ка развијању сасвим специфичног и широког поља студија граница (енгл. boarder studies). Ово дивергентно, хетерогено, мултидисциплинарно истраживачко подручје границе и пограничје поима сасвим широко, те се из перспективе конструктивистичке парадигме границе посматрају и као културни конструкти, формирани кроз различите типове дискурса, надилазећи границе као појам физичког и материјалног простора, тј. као топографску чињеницу (Schimanski, Wolfe, 2010 ${ }^{41}$ ). Другим речима - „Borders, networks and neighbourhoods have both a physical reality in the everyday life of European citizens, and a symbolic and metaphorical dimension at the same time“" (Meinhof, 2011: 3).

Јохан Шимањски и Стивен Волф (Schimanski, Wolfe 2010) у вези са поимањем граница уводе теоријски концепт културне производње који не подразумева само производњу културе, већ и производњу кроз културу, која постаје креативни и перформативни механизам у процесима успостављања граница, те граница постаје и оно о чему се преговара, што се оспорава или се кроз естетске и културе праксе формирају замишљене границе и замишљена погранична подручја (исто: 2-3). Границе су генератори различитих облика културе, бивајући коришћене и као метафоре, чији се значај и економски капитал реализује на пресеку уметности, медија, друштва у целини. Указујући да формирање граница и пограничја није само процес административно-политичке, већ и културне продукције, аутори наглашавају да је реч о феномену који налаже неопходност интердисциплинарног

\footnotetext{
${ }^{40}$ Мирослава Лукић Крстановић термин спектакл одређује као кровни термин за „визуелносценску динамику у зони хипертрофираних симбола“, тј. за праксе које се у литератури означавају на различите начине (у српској хуманистичкој мисли нпр. функционишу термини манифестација, приредба, догађај) (Лукић Крстановић, 2010: 19). Исцрпно анализирајући обимну релевантну литературу, ауторка посебно разматра могућност примене термина у антрополошком дискурсу, те подробно разматра релације спектакл - ритуал, спектакл светковина, спектакл - догађај (исто: 40-62). У вези са односом између ритуала и спектакла, између осталог, истиче: „Црквени обреди ће се прогласити догађајем од изузетног друштвеног и националног значаја, њему ће присуствовати много људи, али и изабрани представници, ређаће се наручени говорници (...) све ће то преносити медији, црквени обред наћи ће се у кућном поседу гледалаца (учесника и неучесника)...“ (исто: 48).

${ }^{41} \mathrm{У}$ наведеној студији дат је аналитички преглед поља проучавања феномена границе и пограничја, те увид у релевантну литературу; в. и Newman, 2003.
} 
приступа у анализама свих пракси које су укључене и у формирање културе памћења.

Представљени усмени наративи откривају границу у индивидуалном менталном простору као стратификован, слојевит и процесуалан феномен. Та се процесуалност односи на њени реалну просторну променљивост, тј. у конкретном случају променљивост њене административно-политичке природе у смислу отворено / затворено; проходно / непроходно (које постаје и опасно). Процесуалност се, потом, дотиче и импликација позиционирања и природе границе не само на домен официјелних административних пракси, већ и на ниво пракси које обликују свакодневицу. Коначно, процесуална природа границе рефлектује се и на динамичност перцепције овог реалног, али и симболичког простора (будући да су управо и реалије везане за контекст пограничја важни елементи симболичког имагинаријума заједнице Срба у Пољадији, обликујћи је и као заједницу сећања и као емоционалну заједницу). Слика обредности везане за Богојављење на Нери истиче се као необичност, специфичност Соколовца (и у виђењу саговорника из других насеља). Експлицитна актуализација проблема идентитета у наведене усмене примере укључена је у различитом степену. Отуда се у неким од наратива комплекс обредно-обичајних радњи везаних за Богојављење на Нери види пре као симболичка тачка разрешења нарација о емоционално напрегнутим аспектима искуства живљења на пољадијској граници. У другима је, пак, наглашенији и доживљај Богојављења на Нери као вида манифестације заједништва Срба са две стране границе. Ипак, сви су саговорници добро обавештени о свим аспектима овог догађаја, а неретко се као посебно интересантни издвајају такмичарски, истичу се победници у пливању за Часни крст и сл. Слика Богојављења коју су понудили саговорници показује се отуда као резултат укрштања индивидуалног искуственог, посредованих знања која циркулишу и усменим путем и путем медија (уз вероватноћу даљег усменог преношења).

Извесно, реална (преосмишљена) обредно-обичајна (сада и институционализована и „спектаклизована“) пракса обележавања Богојављења на Нери добија и нова значења: то више није само ритуал из домена традицијске културе, већ и начин јавног манифестовања заједничког (етничког и културног) идентитета заједница са две стране границе, постајући не само културни, већ и вид потенцијално политичког симболичког капитала.

На самом крају немогуће је не поменути питање динамизма перцепције колективних идентитета, с обзиром на чињеницу да су успостављање границе (пре сада већ више од једног века) и промене њене природе у описаним историјским околностима неминовно донеле и дубоке промене у овом смеру. На овај проблем дискретно упућују сегменти из транскрипата (И ондак скочу и наши, и Румини и Срби, и ко увати крст код тога је крст, после опет догодине тај... [2]; Они сад прођу преко Нере, иду с оне стране 
не песак, преко Нере, то је наш, наша територија, Румуније... [1]; ...почим је разлика у тај сат између вас и нас... [4]), али и општи став Срба из Румуније који сопствени идентитет доживљавају као проблематичан, а који се може сублимирати у исказ: Овде сам Србин, а тамо (у Србији) ме зову Румун, па шта сам ја ${ }^{42}$, како је то дефинисала М. Павловић (2012: 195), а што одговара и подацима које је наш истраживачки тим прикупио током вишегодишњих теренских проучавања српских заједница у Румунији (Поморишје, средњи Банат, Дунавска клисура, Банатска Црна Гора, Пољадија). Даља истраживања овог проблема налажу и укључивање перспективе Срба са друге, српске, стране границе. ${ }^{43}$

\section{Литература}

Беновска-Събкова, 1999: Оброците в Северозападна България: вид религиозно поведение в постсоциалистическо време. Българска етнология 1-2, 7084.

Беновска-Събкова, 2013: Милена Беновска-Събкова, Мъченици и герои: политика на паметта и преоткриване на православието в постсъветска Русия. У: Българският ХХ век. Колективна памет и национална идентичност. Ред. А. Лулева. София: Гутенберг, 249-274.

Бугарски, 1994: Стеван Бугарски, Српско православље у Румунији. Темишварски зборник 1. Нови Сад: Матица српска, 81-90.

Бугарски, Степанов, 2008: Стеван Бугарски и Љубомир Степанов. Историјски и културни споменищи Срба у румунском Банату. Темишвар: Савез Срба у Румунији.

Букуров и др., 1958: Бранислав Букуров, Рајко Николић и Миленко Филиповић, Херска села у Југославији. У: Банатске Хере. Ур. М. Филиповић. Нови Сад: Војвођански музеј у Новом Саду, 38-51.

\footnotetext{
${ }^{42}$ Реч је о отварању проблема регионалних (унутар етничких) идентитета (већу истраживањима спроведеним педесетих година Миленко Филиповић примећује да Срби из Србије Србе у Румунији називају Власима, Филиповић, 1958а: 14), који су у овом случају у актуелном тренутку додатно сложени с обзиром на све израженију тенденцију формирања хибридних идентитета. Наиме, српска заједница у Румунији већ неколико деценија је егзогамна, бројност мешовитих бракова је изразита, а познавање српског језика код припадника млађих генерација је неуједначено.

На подударан начин сопствени етнички идентитет доживљавају нпр. и Срби у Мађарској и Словенији, те се управо синтагме везане за то питање појављују и у насловима монографија ауторки које су се овим проблемима исцрпно бавиле: (Н) и овде (н)и тамо: етнички идентитет Срба у Мађарској на крају ХХ века (Прелић, 2008); Ne tu, ne tam. Srbi v Beli krajini in njihova jezikovna ideologija v procesu zamenjave jezika (Petrović, 2006).

${ }^{43}$ О перцепцији југословенско-румунске (сада српско-румунске) границе из перспективе припадника румунофоних заједница у Србији, на основу опсежних истраживања српског Баната, в. Sikimić, 2014: 68-71.
} 
Букуров, 1958: Бранислав Букуров, Бела Црква. У: Банатске Хере. Ур. М. Филиповић. Нови Сад: Војвођански музеј у Новом Саду, 31-37.

Ђорђевић Белић, 2018: Смиљана Ђорђевић Белић, Здравица: (традиционални?) жанр и савремени контексти. Кюижевна историја 164, 71-106.

Костић, 1930: Слободан Костић, Обнова православног српског манастира Куcића у Румунији 1930. Тимишоара: Штампарија Браћа Чендеш.

Крстић, 1987: Борислав Ђ. Крстић, Код Белог Брешка и око юега. Букурешт: Критерион.

Крстић, 2015: Борислав Ђ. Крстић, Народни живот и обичаји Клисураща и Пољадијаца, Темишвар: Савез Срба у Румунији.

Лукић Крстановић, 2010: Мирослава Лукић Крстановић, Спектакли XX века: музика и моћ. Београд: Етнографски институт САНУ.

Лупуловић, Крстић, 1999: Васа Лупуловић и Борислав Крстић, Соколовац. Темишвар: Савез Срба у Румунији.

Милин А. и др. (ур.) 2011: Андреј Милин, Миодраг Милин и Цветко Михајлов. Срби у Румунији за време комунизма: звучни архив и приручник о страdarby. Sârbii din România în vremea comunismului: arhivă sonoră şi manualul pătimirii. Темишвар: Савез Срба у Румунији.

Милин А., Милин М., 2009: Андреј Милин, Миодраг Милин, ССКДУР или Срби из Румуније на барикадама хладног рата. UACDSR sau sârbii din România pe baricadele războiului rece. Темишвар: Савез Срба у Румунији.

Милин, Мракић, 2011: Миодраг Милин, Горан Мракић, Интервјуи из супротног табора, у: Срби у Румунији: чињенице и подащи из скорије прошлости. Sârbii din România : secvenţe şi date din istoria recentă. Прир. М. Милин. Вршац: Висока школа струковних студија за образовање васпитача „Михаило Палов“, Београд: Српска академија образовања, Arad: Centrul de studii interculturale şi interconfesionale al Universităţii „Aurel Vlaicu“, 162-177.

Милин и Степанов, 2002: Миодраг Милин и Љубомир Степанов, Срби из Румуније у бараганској голготи. Темишвар: Савез Срба у Румунији.

Милин, 2011: Миодраг Милин, Увод. У: Срби у Румунији: чињенице и подаџии из скоpuje прошлости. Sârbii din România: secvenţe şi date din istoria recentă. Прир. М. Милин. Вршац: Висока школа струковних студија за образовање васпитача „Михаило Палов““, Београд: Српска академија образовања, Arad: Centrul de studii interculturale şi interconfesionale al Universităţii „Aurel Vlaicu“, 162-177, 12-21.

Николић, 1958: Рајко Николић, Привредне прилике. У: Банатске Хере. Ур. М. Филиповић. Нови Сад: Војвођански музеј у Новом Саду, 57-68.

Павловић, 2012: Мирјана Павловић. Срби у Темишвару. Београд: Етнографски институт САНУ.

Прелић. 2008: Младена Прелић, (Н)и овде (н)и тамо. Етнички идентитет Срба у Мађарској на крају ХХ века. Београд: Етнографски институт САНУ.

Сикимић, 2018: Биљана Сикимић, Теренска истраживања Срба у Клисури 2017: обичај кумачење. Исходишта 5, 309-322. 
Сореску Маринковић, 2018: Анамарија Сореску Маринковић, $C$ друге стране границе. Југословенска телевизија и друге успомене из свакодневног живота Румуна у Банату. Темишвар: Савез Срба у Румунији.

Степанов Љ. и Степанов В., 2014: Љубомир Степанов и Весна Степанов, Cmaтистички подаци о Србима у Румунији. Темишвар: Савез Срба у Румунији.

Стојковић, 1990: Момир Стојковић, Српска национална мањина у Румунији. У: Сеобе Срба некад и сад. Ур. В. Гречић. Београд: Институт за међународну политику и привреду, Матица Срба и исељеника Србије, 1990, 233-250.

Ћирковић, 2017: Светлана Ћирковић, Настава на српском језику у Поморишју данас. Исходишта 3, 519-536.

Филиповић, 1958а: Миленко Филиповић, Ко су Банатске Хере. У: Банатске Хере. Ур. М. Филиповић. Нови Сад: Војвођански музеј у Новом Саду, 13-14.

Филиповић 1958б: Миленко Филиповић, Постанак и развитак групе банатских Хера. У: Банатске Хере. Ур. М. Филиповић. Нови Сад: Војвођански музеј у Новом Саду, 355-397.

Филиповић (ур.) 1958: Миленко Филиповић, Банатске Хере. Нови Сад: Војвођански музеј у Новом Саду.

Цветковић, 2011а: Владимир Цветковић, Црвена армија на Дунаву. У: Срби у Румунији: чињенице и подации из скорије прошлости. Sârbii din România: secvenţe şi date din istoria recentă. Прир. М. Милин. Вршац: Висока школа струковних студија за образовање васпитача „Михаило Палов“, Београд: Српска академија образовања, Arad: Centrul de studii interculturale şi interconfesionale al Universităţii „Aurel Vlaicu“, 25-39.

Цветковић 2011б, Владимир Цветковић, Преговори у Темишвару 1953. године. У: Срби у Румунији: чињенице и подации из скорије прошлости. Sârbii din România: secvenţe şi date din istoria recentă. Прир. М. Милин. Вршац: Висока школа струковних студија за образовање васпитача „Михаило Палов“, Београд: Српска академија образовања, Arad: Centrul de studii interculturale şi interconfesionale al Universităţii „Aurel Vlaicu“, 86-97.

Церовић, 1997: Љубомир Церовић, Срби у Румунији од раног средњег века до данашњег времена. Нови Сад: Матица српска.

Шандру, 2011: Василе Шандру, Територијалне претензије. У: Срби у Румунији за време комунизма: звучни архив и приручник о страдању. Sârbii din România în vremea comunismului: arhivă sonoră şi manualul pătimirii. Прир. А. Милин, М. Милин и Ц. Михајлов. Темишвар: Савез Срба у Румунији, 308-310.

Baeva, Valtchinova, 2009: Vihra Baeva, Galia Valtchinova, A Women's Religious Organization in Southern Bulgaria: From Miracle Stories to History. History and Anthropology 20/3, 317-338.

Benovska-Sabkova, Nedin, 2016: Milena Benovska-Sabkova, Iliya Nedin, Border territories, border people: the bulgarian town of Zlatograd as a border and a bridge. Антропология. Anthropology. Списание за соичиокулурна антропология. Journal for Sociocultural Anthropology 3, 25-54. 
Borowik i dr, 2004: Irena Borowik, Dinka Marinović Jerolimov i Siniša Zrinščak, Religion and patterns of social transformation - or: how to interpret religious changes in post-communism?. U: Religion and patterns of social transformation. Eds. I. Borowik, D. Marinović Jerolimov i S. Zrinščak. Zagreb: Institute for social research, 9-19.

Gog, 2006: Sorin Gog, The construction of the religious space in post-socialist Romania. Journal for the Study of Religions and Ideologies 15, 37-53.

Meinhof, 2011: Ulrike Hanna Meinhof, Introducing Borders, Networks, Neighbourhoods: Conceptual Frames and Social Practices. Y: Negotiating Multicultural Europe: Borders, Networks, Neighbourhoods. Eds. H. Armbruster, U. H. Meinhof. Palgrave Macmillan UK, 1-24.

Milin M. i dr., 2011: Miodrag Milin, Andrei Milin, Alexandra Bogdanovici, Cvetko Mihajlov, Политички затвореници. У: Срби у Румунији: чињенице и подащи из скорије прошлости. Sârbii din România: secvenţe şi date din istoria recentă. Прир. М. Милин. Вршац: Висока школа струковних студија за образовање васпитача „Михаило Палов“, Београд: Српска академија образовања, Arad: Centrul de studii interculturale şi interconfesionale al Universităţii „Aurel Vlaicu“, 110-162.

Naumović, 1996: Slobodan Naumović, Od ideje obnove do prakse upotrebe : ogled o odnosu politike i tradicije na primeru savremene Srbije. Од мита до фолка. Лииеум 2. Ур. М. Детелић. Крагујевац: Центар за научна истраживања САНУ и Универзитета у Крагујевцу, 109-145.

Naumović, 2009: Slobodan Naumović, Upotreba tradicije u političkom i javnom životu Srbije na kraju dvadesetog i početkom dvadeset prvog veka. Beograd: Institut za filozofiju i društvenu teoriju „Filip Višnjić““.

Nistor, 2015: Ionuţ Nistor: „Procesul titoismului “ în România (1950). Documente, Iaşi.

Newman, 2003: David Newman, On Borders and Power: A Theoretical Framework. Journal of Borderlands Studies 18/1, 13-25.

Perica, 2006: Vjekoslav Perica, Balkanski idoli: religija inacionalizam ujugoslovenskim državama. Beograd: Biblioteka XX vek.

Petrović, 2006: Tanja Petrović, Ne tu, ne tam. Srbi v Beli krajini in njihova jezikovna ideologija v procesu zamenjave jezika. Ljubljana: Založba ZRC.

Popi, 1976: Popi, Gligor, Rumuni u jugoslovenskom Banatu između dva rata (19181941). Novi Sad: Institut za izučavanje istorije Vojvodine.

Radulović, 2012: Lidija Radulović, Religija ovde i sada. Revitalizacija religije u Srbiji. Beograd: Srpski genealoški centar, Odeljenje za etnologiju i antropologiju Filozofskog fakulteta.

Radulović, 2014: Lidija Radulović, Bog kao privatna stvar: kultura sećanja i religijski život u vreme socijalizma. Етноантрополошки проблеми 9/1, 35-48.

Sikimić, 2014: Biljana Sikimić, Romanians in Serbian Banat: Dynamic Epystemology. The Multilingual Society Vojvodina. Intersecting Borders, Cultures and Identities. Eds. T. Kamusella, M. Nomachi. Sapporo: Slavic Research Center, Hokkaido University, 51-73. 
Sorescu-Marinković, 2010: Annemarie Sorescu-Marinković, Serbian Language Aquisition in Communist Romania. Balcanica XLI, 7-31.

Sorescu-Marinkovic, 2016: Annemarie Sorescu-Marinkovic, Contemporary Romanian migrations to Serbia: stages, actors, reasons. Balcanica Posnaniensia. Acta et stu dia XXIII. Poznań: Wydawnictwo Instytutu Historii UAM, 151-165.

Schimanski, Wolfe, 2010: Johan Schimanski, Stephen Wolfe. Cultural Production and Negotiation of Borders: Introduction to the Dossier. Journal of Borderlands Studies 25/1, 39-49.

\section{Интернет извори}

https://www.facebook.com/bogojavljenjenaneri/videos/467677100582332/), приступљено 12. 2. 2020.

http://radiobelacrkva.rs/bogojavljenje-na-reci-neri-video/, приступљено 10. 2. 2020. http://infobc.rs/tag/vracev-gaj/, приступљено 10. 2. 2020.

http://www.tvbanat.com/emisije/442/bogojavljenje-na-neri, приступљено 10. 2. 2020. http://www.belacrkvato.org/, приступљено 10. 2. 2020.

https://www.vesti-online.com/duhovni-most-preko-nere/?fbclid=IwAR1TGw9OZVI WWetxWih8xKSKQLifNJGUkT0fFGA5GqeIEqZrPiSJQxQqkPk, приступљено 1. 3. 2020.

https://www.facebook.com/comuna.socol/videos/854906441221879/UzpfSTIwOTEz NzQwNTgxNzIxMTo4NDc3NjY1Mzg2MjA5NTg/, приступљено 15. 8. 2019. https://www.facebook.com/bogojavljenjenaneri/videos/232737430937949/, приступљено 15. 8. 2019.

Smiljana Ž. Đorđević Belić

\section{(RE)SEMANTIZATION OF THE THEOPHANY FEAST ON THE NERA RIVER IN THE CONTEXT OF BORDERLAND PERCEPTION}

\section{Summary}

The study examines the current practice of celebrating Theophany on the Nera River (January $19^{\text {th }}$ on the on Calendar of the Serbian Orthodox church marks the day Jesus Christ was baptized in the River Jordan by John the Baptist), based on field surveys conducted in Poljadija (Romania, settlements Langovet / Lugovet (Romanian: Câmpia), Zlatica (Rom. Zlatiţa) and Sokolovac (Rom. Socol)). Namely, a ritual procession was (re)established there since 1990: after the liturgy, a religious procession proceeds to Nera, where a priest performs the sanctification of the river; 
swimming for the Holy Cross became part of the ritual praxis as well; apart from the inhabitants of the borderland villages, Sokolovac (Romania) and Vračev Gaj (Serbia), church dignitaries and representatives of political institutions also take part in the ritual. The first part of the paper offers an overview of the basic historical data related to the Serbian community in Romania in recent history, as a basis for a better understanding of the historical events and realia mentioned by the interlocutors in their Theophany-related discourse. The second part reviews the ethnographic descriptions of the Theophany celebrations in this area dated before 1990, as well as commented transcripts of field interviews. The third segment appraises the functions of the Theophany on Nera as a topic in public discourse (local media and newsletters of the Serbian minority in Romania, Serbian media, including web portals aimed at a wider audience, the Facebook page Theophany on Nera, as well as content from other social networks). Finally, the concluding chapter views the current practice in an ideologicalhistorical context (retraditionalization in post-socialist societies, homogenization of national identities, etc.), in the context of the "spectacularization" of rituals, and in the context of border studies. The boundary thus proves to be a stratified, layered and processual phenomenon in the interlocutors' view, and the real (rethought) ritual and customary practice (now institutionalized and "spectacularized") of celebrating Epiphany on the Nera also takes on new meanings: it is no longer merely a ritual in the realm of traditional culture, but also a way of publicly manifesting the common (ethnic and cultural) identity of Serbain communities on both sides of the border, having become not only cultural symbolic capital but a form of potentially political symbolic capital as well.

Keywords: Theophany feast, Serbs in Romania, ritual, institutionalization, oral history, media discourse, borderland, boarder studies 